\title{
A multiplex PCR approach for the molecular identification and conservation of the Critically Endangered daggernose shark
}

\author{
Pedro G. Nachtigall ${ }^{1 *}$, Luis F. S. Rodrigues-Filho ${ }^{2}$, Davidson C. A. Sodré ${ }^{2}$, \\ Marcelo Vallinoto ${ }^{2}$, Danillo Pinhal ${ }^{1}$ \\ ${ }^{1}$ Departamento de Genética, Instituto de Biociências, Universidade Estadual Paulista - UNESP, Botucatu, SP 18618-970, Brazil \\ ${ }^{2}$ Instituto de Estudos Costeiros (IECOS), Universidade Federal do Pará - UFPA, Bragança, PA, Brazil
}

\begin{abstract}
The daggernose shark Isogomphodon oxyrhynchus is an inshore tropical species endemic to the coastal waters off northeastern South America with limited distribution and restrictive biological traits. According to the IUCN, this species is Critically Endangered owing to a dramatic population decline over the past $10 \mathrm{yr}$. Here we implemented a multiplex PCR methodology based on species-specific primers for the precise identification of samples from the daggernose shark (body parts and fins). The effectiveness of the method was verified through application for analysis of unidentified shark samples collected in fish markets and a worldwide inventory of over 57 shark species. This reliable molecular system of identification combines the advantages of low cost and high throughput and may be used locally to monitor the capture and trade of this Critically Endangered shark species.
\end{abstract}

KEY WORDS: Genetic identification $\cdot$ ITS2 $\cdot$ Multiplex PCR $\cdot$ Sharks $\cdot$ DNA forensics

\section{INTRODUCTION}

The daggernose shark Isogomphodon oxyrhynchus is a tropical inshore species with a restricted natural range, inhabiting shallow waters of the western Atlantic from Trinidad to northern Brazil (Compagno 1984; our Fig 1). Its distribution is associated with hot, humid climates and highly turbid waters where mangroves are the dominant system (Lessa et al. 1999). The species has biological parameters that limit population growth, including low fecundity ( 2 to 8 pups), late sexual maturity, long gestation period (1 yr) and a biennial reproductive cycle. I. oxyrhynchus is under intense fishing pressure across its entire range, being caught incidentally in floating gillnets by artisanal fisheries. Limited available data from demographic analyses suggest that the $I$. oxyrinchus population has been decreasing at $\sim 18 \%$ per year with huge declines ( $>90 \%$ ) resulting over the

*Corresponding author: pedronachtigall@gmail.com past 14 yr (Santana \& Lessa 2002, Lessa et al. 2006). Considering its biological traits, and the fact that it is over-exploited by fisheries in its restricted occurrence area, the daggernose shark is listed as Critically Endangered by the IUCN (Lessa et al. 2006), as a species that needs urgent management and conservation to prevent it from becoming extinct.

Correct statistical data from fisheries is of utmost importance for designing conservation measures. However, this task is hampered by the fact that the finning process, where fins and/or body parts of shark species are removed, makes correct species identification difficult. Genetic profiling has thus become a widely used method for forensic identification of marine species for the purposes of trade monitoring and fisheries management (Heist 2005, Ogden et al. 2009). For instance, genetic profiling has been used to quantify global fin landings, detect illegal captures and identify the geographic origin of

() The authors 2017. Open Access under Creative Commons by Attribution Licence. Use, distribution and reproduction are unrestricted. Authors and original publication must be credited. 


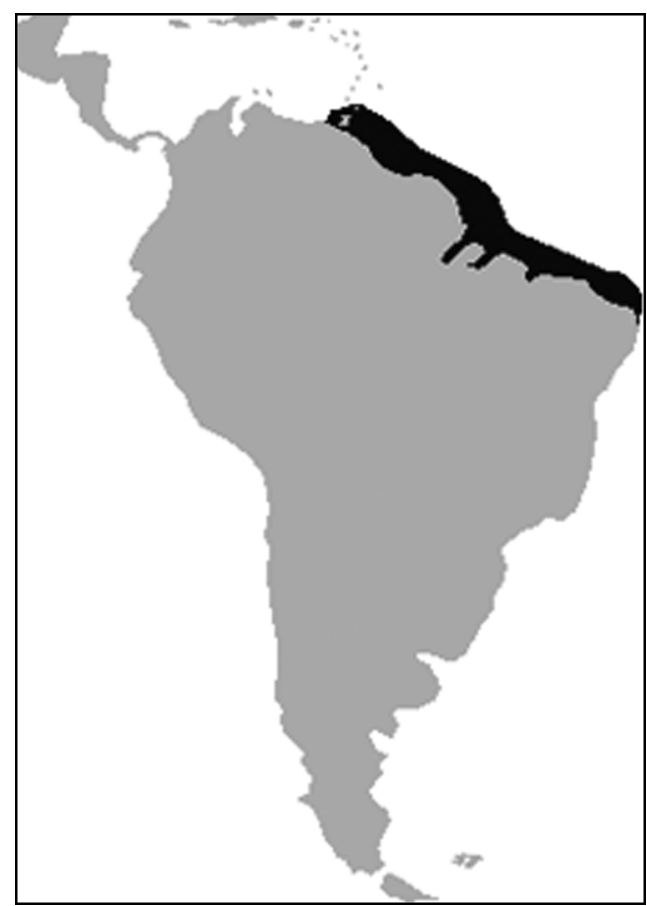

Fig. 1. Geographical distribution (black shading) of the daggernose shark Isogomphodon oxyrhynchus on the northeastern coast of South America

traded shark parts (reviewed in Shivji 2010). In this context, several studies report efforts to develop molecular markers for the correct identification of endangered shark species in fisheries landings (Chapman et al. 2003, Feldheim et al. 2010).

Several markers such as cytochrome oxidase subunit I (COI), cytochrome B and 16S have proven useful as a DNA barcoding method to identify body parts landed from fisheries. However, due to the lengthy sequencing procedures involved, such methodologies are still expensive and time consuming (Dudgeon et al. 2012). Thus, the validation of less expensive, reliable and easy-to-use tools for monitoring shark exploitation in developing countries is required.

Among the diverse PCR-based methods so far developed, a multiplex PCR-based method designed by Pank et al. (2001) has been very useful and enabled correct genetic identification of several shark species worldwide (Shivji et al. 2002, Chapman et al. 2003, Abercrombie et al. 2005, Magnussen et al. 2007, Pinhal et al. 2012). This rapid, low-cost and highly reproducible methodology requires only PCR for species identification, without additional DNA sequencing or cleavage by enzymatic processing. It employs a combination of universal and species-specific primers (SSPs) of the nuclear ribosomal DNA internal transcribed spacer 2 (ITS2) locus in a singlereaction, producing a unique diagnostic profile for each target species. Although several SSPs had already been developed prior to our study, these were only applicable to a few of the many shark species known worldwide.

Therefore, taking into account the restrictive biological traits and the endangered status of daggernose sharks in the wild, we designed and validated a triplex PCR-based assay for the genetic identification of daggernose shark by-products from fisheries. Our assay expands the repertoire of SSPs available and can be implemented for fast and accurate identification of this target species in order to assist in both local conservation and trade monitoring.

\section{MATERIALS AND METHODS}

\section{Shark sampling and DNA extraction}

Daggernose shark samples were collected from 10 wild specimens caught by artisanal and commercial fisheries along the north coast of Brazil from 2009 to 2014. The 10 specimens were morphologically identified and confirmed by specialists. Fins and muscle samples were preserved in $95 \%$ ethanol and kept at $-20^{\circ} \mathrm{C}$ for long-term storage.

Total genomic DNA was isolated following the phenol-chloroform protocol (Sambrook \& Russel 2006) with modifications and stored at $-20^{\circ} \mathrm{C}$ until use. The DNA integrity was accessed by $1 \%$ agarose gel stained with GelRed (Uniscience) and quantified with NanoDrop-1000 (Thermo Scientific).

For diagnostic validation, the putative speciesspecific daggernose primer was also tested against 57 non-target shark species provided by colleagues from Brazil, USA and Australia. Data for both target and non-target shark species, including geographic source and sample sizes are presented in Table 1. The nontarget species tested for primer specificity control included species closely related to daggernose sharks and commonly caught by fisheries worldwide (in some cases by the same local fisheries), as well as other shark species from several distinct oceanic areas.

\section{PCR amplification and sequencing of ITS2 locus}

The whole sequence of the ITS2 region was amplified using the universal primers FISH5.8SF and FISH28SR following the PCR conditions described by Pank et al. (2001). Amplified segments were visual- 
Table 1. Inventory of target and non-target shark species tested with daggernose shark species-specific primers (SSPs) in triplex PCR assays. Geographic ocean basin origins of the shark test species are shown, together with the number of individuals of each species tested from each geographic region. The target species is shown in bold

\begin{tabular}{|c|c|c|c|}
\hline Species & $\begin{array}{l}\text { Geographic } \\
\text { origin (number } \\
\text { tested) }\end{array}$ & Species & $\begin{array}{l}\text { Geographic } \\
\text { origin (number } \\
\text { tested) }\end{array}$ \\
\hline \multicolumn{2}{|l|}{ ORDER CARCHARHINIFORMES } & \multirow[t]{2}{*}{ Carcharhinus amboinensis (pigeye) } & Pacific (2); \\
\hline Isogomphodon oxyrhynchus (daggernose shark) & Atlantic (10) & & Indian (3) \\
\hline Rhizoprionodon lalandei (Brazilian sharpnose) & Atlantic (5) & \multirow[t]{2}{*}{ Carcharhinus brachyurus (bronze whaler) } & Atlantic (2); \\
\hline Rhizoprionodon porosus (Caribbean sharpnose) & Atlantic (5) & & Pacific (3) \\
\hline Rhizoprionodon terranovae (Atlantic sharpnose) & Atlantic (5) & Carcharhinus tilstoni (Australian blacktip) & Pacific (5) \\
\hline Rhizoprionodon longurio (Pacific sharpnose) & Pacific (6) & Carcharhinus sorrah (spot-tail) & Índian (2); \\
\hline Rhizoprionodon acutus (milk shark) & Pacific (5) & & Pacific (4) \\
\hline Rhizoprionodon taylori (Australian sharpnose) & Pacific (5) & Carcharhinus amblyrhynchos (gray reef) & Pacific (5) \\
\hline Rhizoprionodon oligolinx (grey sharpnose) & Indian (2) & Negaprion brevirostris (lemon) & Atlantic (5) \\
\hline \multirow[t]{2}{*}{ Sphyrna mokarran (great hammerhead) } & Atlantic (3); & Negaprion acutidens (sicklefin lemon) & Pacific (5) \\
\hline & Pacific (2) & Mustelus norrisi (smoothhound) & Atlantic (2) \\
\hline \multirow[t]{2}{*}{ Sphyrna lewini (scalloped hammerhead) } & Atlantic (5); & Mustelus canis (smooth dogfish) & Atlantic (6) \\
\hline & Pacific (3) & Mustelus californicus (grey smoothhound) & Pacific (1) \\
\hline \multirow[t]{2}{*}{ Sphyrna zygaena (smooth hammerhead) } & Atlantic (5); & Triakis semifasciata (leopard) & Pacific (1) \\
\hline & Pacific (3) & Scyliorhinus sp. (catshark) & Atlantic (6) \\
\hline Sphyrna tiburo (bonnethead) & Atlantic (5) & Apristurus profundorum (deep-water catshark) & Atlantic (1) \\
\hline Sphyrna tudes (golden hammerhead) & Atlantic (5) & \\
\hline Eusphyra blochii (winghead) & Pacific (1) & \multirow{2}{*}{$\begin{array}{l}\text { ORDER LAMNIFORMES } \\
\text { Isurus oxyrinchus (shortfin mako) }\end{array}$} & \\
\hline Loxodon macrorhinus (sliteye) & Atlantic (6) & & Atlantic (6); \\
\hline Galeocerdo cuvier (tiger) & $\begin{array}{l}\text { Atlantic (5); } \\
\text { Pacific (3) }\end{array}$ & Isurus paucus (longfin mako) & $\begin{array}{l}\text { Pacific (3) } \\
\text { Atlantic (2); }\end{array}$ \\
\hline \multirow{2}{*}{$\begin{array}{l}\text { Triaenodon obesus (whitetip reef) } \\
\text { Prionace glauca (blue shark) }\end{array}$} & Pacific (5) & \multirow[b]{2}{*}{ Lamna nasus (porbeagle) } & Pacific (2) \\
\hline & Atlantic (7); & & $\begin{array}{l}\text { Atlantic (2); } \\
\text { Pacific (3) }\end{array}$ \\
\hline Carcharhinus altimus (bignose) & $\begin{array}{l}\text { Atlantic (3); } \\
\text { Pacific (2) }\end{array}$ & \multirow[t]{2}{*}{ Carcharodon carcharias (white shark) } & $\begin{array}{l}\text { Atlantic (2); } \\
\text { Indian (3); } \\
\text { Pacific (3) }\end{array}$ \\
\hline \multirow[t]{2}{*}{ Carcharhinus longimanus (oceanic whitetip) } & Atlantic (2); & & Pacific (3) \\
\hline & Pacific (3) & Alopias vulpinus (thresher) & Atlantic (1) \\
\hline Carcharhinus signatus (night) & Atlantic (5) & Alopias superciliosus (bigeye thresher) & Atlantic (5) \\
\hline Carcharhinus plumbeus (sandbar) & $\begin{array}{l}\text { Atlantic (2); } \\
\text { Pacific (3) }\end{array}$ & \multirow[t]{2}{*}{ Carcharias taurus (sand tiger) } & $\begin{array}{l}\text { Atlantic (2); } \\
\text { Indian (2); }\end{array}$ \\
\hline Carcharhinus obscurus (dusky) & Atlantic (2); & & Pacific (2) \\
\hline Carcharhinus limbatus (blacktip) & $\begin{array}{c}\text { Pacific (3) } \\
\text { Atlantic (3); } \\
\text { Pacific (3) }\end{array}$ & \multirow{2}{*}{$\begin{array}{l}\text { ORDER ORECTOLOBIFORMES } \\
\text { Ginglymostoma cirratum (nurse) } \\
\text { Nebrius ferrugineus (tawny nurse) }\end{array}$} & Atlantic (10) \\
\hline \multirow[t]{3}{*}{ Carcharhinus falciformis (silky) } & Atlantic (2); & & Pacific (1) \\
\hline & Pacific (2); & ORDER SQUALIFORMES & \\
\hline & Indian (1) & Squalus acanthias (spiny dogfish) & Atlantic (4) \\
\hline Carcharhinus porosus (smalltail) & Atlantic (5) & Centrophorus squamosus (leafscale gulper) & Atlantic (1) \\
\hline Carcharhinus galapagensis (Galapagos) & Pacific (5) & ORDER SQUATINIFORMES & \\
\hline Carcharhinus leucas (bull) & $\begin{array}{l}\text { Atlantic (8); } \\
\text { Pacific (3) }\end{array}$ & Squatina californica (Pacific angel) & Pacific (2) \\
\hline Carcharhinus isodon (finetooth) & Atlantic (5) & ORDER HEXANCHIFORMES & \\
\hline Carcharhinus acronotus (blacknose) & Atlantic (5) & Hexanchus griseus (sixgill) & Pacific (2) \\
\hline Carcharhinus perezi (Caribbean reef) & Atlantic (5) & Heptranchias perlo (sharpnose sevengill) & Atlantic (1) \\
\hline
\end{tabular}

ized on a $1.2 \%$ agarose gel stained with GelRed under UV light. The products were purified with the illustra ExoProStar 1-Step kit (GE Healthcare Life Sciences) according to the manufacturer's protocol.

Sequencing reactions were performed with the BigDye Terminator v3.1 kit (Applied Biosystems), according to the manufacturer's protocol. The cycling profile comprised an initial denaturation at $95^{\circ} \mathrm{C}$ for 5 min, followed by 35 cycles of denaturation at $95^{\circ} \mathrm{C}$ for $1 \mathrm{~min}$, annealing at $50^{\circ} \mathrm{C}$ for $30 \mathrm{~s}$ and extension at $60^{\circ} \mathrm{C}$ for $1 \mathrm{~min}$. The products were gel purified using the DyeEx 2.0 Spin Kits (Qiagen), and sequencing was carried out on an Applied Biosystems 3130 DNA analyzer (Applied Biosystems). The final ITS2 locus 
sequence obtained was analyzed with the software Geneious (version 4.8.5, Biomatters; Drummond et al. 2009).

\section{Primer design and multiplex PCR}

Complete ITS2 locus sequences obtained from the daggernose sharks were aligned with GenBank sequences of closely related species using Geneious (as above). Several putative species-specific primers (SSPs) were designed for daggernose shark based on the nucleotide differences detected between the target species and closely related non-target species sequences using Geneious (Drummond et al. 2009) and OligCalc (Kibee 2007). The putative SSPs were designed as reverse primers to, and initially tested against, closely related species in a PCR triplex format including the SSP with the forward and reverse universal ITS2 primers (Pank et al. 2001). Two amplification products are expected from the target species with this triplex PCR: a species-characteristicsized PCR amplicon generated by the reverse SSP in conjunction with the forward ITS2 universal primer, and a positive control amplicon generated by the 2 ITS2 universal primers (Fig. 2). In contrast, the PCR product from other species is expected to yield only the positive control amplicon, due to the fact that no annealing site of the SSP is present in the genomic DNA of the non-target species (Pank et al. 2001).

Several inspections of temperature and extension time were applied to the triplex-PCR for standardization. This resulted in the following optimized conditions: denaturation at $94^{\circ} \mathrm{C}$ for $4 \mathrm{~min}$, followed by 35 cycles at $94^{\circ} \mathrm{C}$ for $1 \mathrm{~min}$, $65^{\circ} \mathrm{C}$ for $1 \mathrm{~min}$ and $72^{\circ} \mathrm{C}$ for $2.5 \mathrm{~min}$, and a 5 min final extension at $72^{\circ} \mathrm{C}$. PCR reactions consisted of $30 \mathrm{ng}$ of DNA, $400 \mathrm{nmol}$ of each primer, $2.5 \mathrm{mM}$ of $\mathrm{MgCl}_{2}, 1 \times$ PCR buffer, $200 \mu \mathrm{M} d N T P s$ and 1 unit of Platinum Taq DNA polymerase (Invitrogen). Amplifications were carried out in a PTC-200 (MJ Research) thermal cycler and checked through a $1.2 \%$ agarose gel stained with GelRed under UV light. Eight closely related species of Carcharhinus were utilized for the initial test of the
SSPs designed. Then, the putative SSP that consistently amplified the correct-sized fragment for the daggernose shark and presented no amplification in the 8 closely related species (see Table 2 for primer sequence) was chosen for further tests against 49 additional non-daggernose shark species, totaling 57 species and 279 individuals (see Table 1 for additional information), representative of the wide variety of species that are known to be commonly taken by fisheries. This test further confirmed the specificity of the primer which exclusively amplified in the presence of daggernose shark DNA.

\section{Market screening}

The daggernose shark SSP developed in this study and SSPs developed by others for non-daggernose shark species (Pank et al. 2001, Chapman et al. 2003, Abercrombie et al. 2005, Pinhal et al. 2012) were successfully used for screening shark body parts from markets. All samples were tested against all assays. A total of 51 samples of unknown species were sourced from the fish markets in Bragança, PA, on the north coast of Brazil (an area within the distribution range of the daggernose shark) and screened

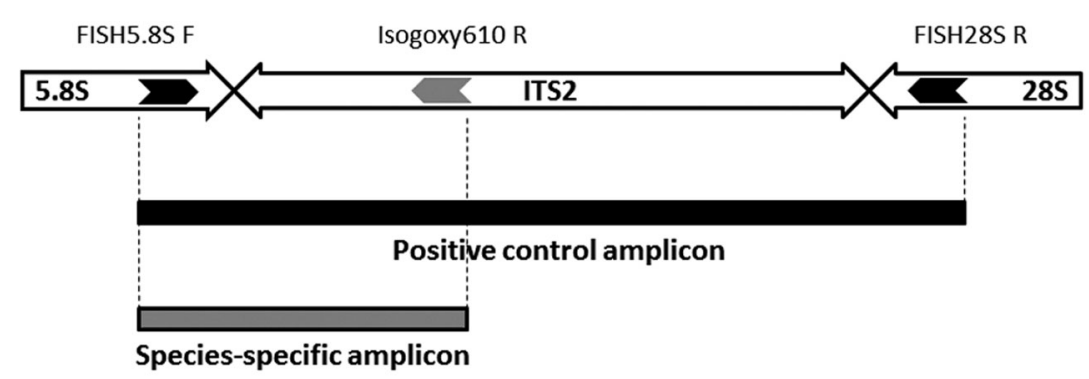

Fig. 2. Schematic representation of the shark nuclear 5.8S and $28 \mathrm{~S}$ ribosomal RNA genes and ITS2 locus showing the annealing sites and orientation of primers of the universal shark primers (black) and species-specific primer for Isogomphodon oxyrhynchus (gray) used in triplex PCR assay. Black and gray bars represent the spatial coverage of the 2 amplicons expected to be produced using this combination of 3 primers when tested against target DNA. In contrast, only the positive control amplicon would be produced in the absence of the tar get species. Figure adapted from Shivji et al. (2002)

Table 2. Shark universal and daggernose shark species-specific primer (SSP) used in the triplex assay. Note that primers FISH5.8S-F and FISH28S-R were developed previously by Pank et al. (2001)

\begin{tabular}{|ll|}
\hline Primer & Sequence \\
\hline FISH5.8S-F & 5'-TTA GCG GTG GAT CAC TCG GCT CGT-3' \\
FISH28S-R & 5'-TCC TCC GCT TAG TAA TAT GCT TAA ATT CAG C-3' \\
Isogoxy-610-ITS2 & 5'-CGG CCC CCT CCT GGC TG-3' \\
\hline
\end{tabular}


against all assays. Furthermore, the common names of the samples given by the sellers at fish markets were recorded for comparison with the results of our screening analysis, with the aim of verifying the accuracy of identifications made by the sellers. After identification by SSPs, the ITS2 locus of the 51 samples obtained for screening was sequenced, as described above. Sequences were matched against 10 daggernose shark ITS2 sequences acquired in the present study and to ITS2 sequences from another 22 shark species available from GenBank.

\section{RESULTS}

\section{Evaluating the species-specific primer}

The triplex PCR assay developed for daggernose sharks was effective for species diagnosis. The ITS2 locus control amplicon recovered for this species was about $1450 \mathrm{bp}$. The ITS2 sequences recovered presented low intraspecific variability for the 10 samples analyzed (99.6\% of average similarity).

The amplicon generated by the SSP was $610 \mathrm{bp}$ and was specific for the identification of daggernose shark body parts, whereas the control amplicon of non-target species was variable, ranging from 800 to $1650 \mathrm{bp}$ (Fig. 3). The low-frequency appearance of a third high molecular weight amplicon ( 4000 bp) on the target species was due to the amplification of 2 tandem repeats of the locus $45 \mathrm{~S}$ rDNA, and does not interfere with the accuracy and effectiveness of the current methodology.

\section{Market screening}

Of the 51 samples acquired at the market, 4 were listed by fisherman and sellers as body parts from daggernose sharks. However, our molecular screening showed that these 4 samples were not from daggernose sharks, but came from other sympatric shark species. This suggests that the statistical data based on landing and identification by sellers (who are also the fishers) lead to errors, which could affect fisheries management. Market samples identified included 29 from the genus Rhizoprionodon (20 R. porosus and 9 R. lalandei), 7 blue sharks Prionace glauca, 6 shortfin mako sharks Isurus oxyrhinchus, 3 scalloped hammerhead sharks Sphyrna lewini and 6 from the genus Carcharhinus (4 C. porosus, 1 C. obscurus and 1 C. falciformis). Posterior sequencing of all shark samples obtained from the markets confirmed beyond doubt their identification made using SSPs (data available from the authors on request).

\section{DISCUSSION}

The daggernose shark SSP only amplified reliably for daggernose shark. Furthermore, the large dataset evaluated (289 total samples) confirmed its potential species-diagnostic utility. The ITS2 locus has been proved to be an excellent marker for genetic identification of shark species, capable of distinguishing clearly among closely related congeneric species (Pank et al. 2001, Shivji et al. 2002, Chapman et al. 2003, Pinhal et al. 2012). Moreover, the ITS2 locus belongs to the $45 \mathrm{~S}$ ribosomal DNA tandem repeats (Lewin 2004), indicating the existence of a large number of primer annealing sites, which facilitates PCR amplification even with minor amounts of template DNA (Chapman et al. 2003, Mukherjee et al. 2007). The ITS2 region has been shown by diverse 
studies to have enough resolution for species identification (Yao et al. 2010, Doukakis et al. 2011, Marino et al. 2015). All the data obtained for this region showed that ITS2 presents a low intraspecific polymorphism and high interspecific variability even for closely related species (Pinhal et al. 2012), which confirms the potential of ITS2 locus to be used for the development of SSPs. Related to our data, we performed 2 ClustalW alignments, showing (1) the low level of intraspecific variability for daggernose shark ITS2 loci (see Supplement 1 at www.int-res.com/ articles/suppl/n032p169_supp.pdf), and (2) the high interspecific variability among shark species (Supplement 2; URL as above). All these results confirm the ability of this methodology to correctly identify daggernose shark body parts landed in bays and sold in markets worldwide. Our methodology permits the genetic identification of the species in one single tube reaction with no need for extra sequencing steps or restriction enzyme treatment (e.g. PCR-RFLP method), and is faster and less expensive than DNA barcoding. All these characteristics are critical for introducing molecular approaches to wildlife monitoring in developing countries. Nevertheless, it is important to point out that DNA barcoding provides, in most cases, unambiguous identification of which shark species the body part belongs to. The multiplex PCR-based methodology determines only whether the sample was acquired from the target species or not. Thus, the choice of method will be determined by the aims and scope of the study at hand.

The genetic identification of samples from the market was different from the identification of the corresponding body parts by fishermen and sellers. Market screening using molecular genetics provides a powerful tool to confirm the identity of shark species and to trace sampled individuals back to their original area of capture (Chapman et al. 2009). However, the results of our study indicate that information on shark landings provided by fishermen and sellers is not reliable and may therefore be inadequate for management of shark species. The daggernose shark is not listed in CITES Appendices I or II; however, given its Critically Endangered classification, it should be listed in Appendix I. In 2009, it was included in 'Anexo 1' of the Brazilian Institute of the Environment and Renewable Natural Resources (IBAMA). This listing prohibits the commercialization of the entire or body parts of this species in Brazil. However, there have been no records of this species from fisheries monitoring since 2009, suggesting that its conservation status is worse than indicated in official trade reports from IBAMA. This absence from the statistics could be the result of (1) errors in fisheries records; (2) lack of management in the area where the species occurs; (3) failure to record sharks caught and discarded at sea; and/or (4) the finning process, which leads to errors in, and absence of, records since the sharks' bodies are missing parts and thus also morphological characteristics needed for correct species identification. However, the considerable doubt that even moderate exploitation pressure can be sustained highlights the need for reliable information about the current exploitation level of this species to inform planning, and management and conservation strategies.

\section{CONCLUSIONS}

Shark species are being overexploited around the world and the exploitation rate is unsustainable (Worm et al. 2013). Therefore, efforts to improve trade monitoring and fisheries management are crucial for species conservation. In the current study, we presented a simple low-cost and efficient tool that can be easily applied for identification of body parts from the daggernose shark Isogomphodon oxyrhynchus, a Critically Endangered species under intense fishing pressure across its natural distribution area. Considering that the occurrence of this species is primarily restricted to marine areas belonging to developing countries, the low cost of this PCR-based methodology allows its implementation as a straightforward routine for trade monitoring and fisheries management.

Data accessibility. Daggernose shark ITS2 sequence: GenBank accession nos. KU556288 to KU556297.

Acknowledgements. We thank Dr. Mahmood S. Shivji from Guy Harvey Research Institute (GHRI) for providing DNA aliquots of several shark species; Dr. Cesar Martins for lab support; the Instituto de EstudosCosteiros (IECOS) for daggernose shark and market screening samples; and the 'Fundação de Amparo à Pesquisa do Estado de São Paulo' (FAPESP) for financial support (grant numbers 07/3067-8; 07/3065-5; and 13/06864-7).

\section{LITERATURE CITED}

Abercrombie DL, Clarke SC, Shivji M (2005) Global-scale genetic identification of hammerhead sharks: application to assessment of the international fin trade and law enforcement. Conserv Genet 6:775-788

Chapman DD, Abercrombie DL, Douady CJ, Pikitch EK, Stanhope MJ, Shivji MS (2003) A streamlined, biorganelle, multiplex PCR approach to species identifi- 
cation: application to global conservation and trade monitoring of the great white shark, Carcharodon carcharias. Conserv Genet 4:415-425

Chapman DD, Pinhal D, Shivji MS (2009) Tracking the fin trade: genetic stock identification in western Atlantic scalloped hammerhead sharks Sphyrna lewini. Endang Species Res 9:221-228

Compagno LJV (1984) Sharks of the world: an annotated and illustrated catalogue of shark species known to date. FAO species catalogue, Vol 4. FAO, Rome

Doukakis P, Hanner R, Shivji M, Bartholomew C, Chapman D, Wong E, Amato G (2011) Applying genetic techniques to study remote shark fisheries in northeastern Madagascar. Mitochondrial DNA 22 Supp1 1:15-20

Drummond AJ, Ashton B, Cheung M, Heled J and others (2009) Geneious v4.6. www.geneious.com/

* Dudgeon CL, Blower DC, Broderick D, Giles JL and others (2012) A review of the application of molecular genetics for fisheries management and conservation of sharks and rays. J Fish Biol 80:1789-1843

Feldheim KA, Chapman DD, Simpendorfer CA, Richards VP and others (2010) Genetic tools to support the conservation of the endangered smalltooth sawfish, Pristis pectinata. Conserv Genet Resour 2:105-113

Heist EJ (2005) Population and reproductive genetics in Chondrichthyes. In: Hamlett WC (ed) Reproductive biology and phylogeny of Chondrichthyes: sharks, skates, stingrays, and chimaeras. Science Publishers, Plymouth

Kibee WA (2007) OligoCalc: an online oligonucleotide properties calculator. Nucleic Acids Res 35 Suppl 2:W43-W46

Lessa RPT, Da Batista VS, Alemida ZS (1999) Occurrence and biology of the daggernose shark Isogomphod onoxyrhynchus (Chondrichthyes: Carcharhinidae) off the Maranhão coast (Brazil). Bull Mar Sci 64:115-128

Lessa RPT, Charvet-Almeida P, Santana FM, Almeida, ZS (2006) Isogomphod onoxyrhynchus. The IUCN Red List of Threatened Species 2006: e.T60218A12323498. http:// dx.doi.org/10.2305/IUCN.UK.2006.RLTS.T60218A12323 498.en

Lewin B (2004) Genes VIII, 8th edn. Pearson Prentice Hall, Upper Saddle River, NJ

Magnussen JE, Pikitch EK, Clarke SC, Nicholson C, Hoelzel AR, Shivji MS (2007) Genetic tracking of basking shark (Cetorhinus maximus) products in international trade. Anim Conserv 10:199-207

Marino IAM, Riginella E, Cariani A, Tinti F, Farrell ED, Mazzoldi C, Zane L (2015) New molecular tools for the iden-

Editorial responsibility: Paolo Casale,

Rome, Italy tification of two endangered smooth-hound sharks, Mustelus mustelus and Mustelus punctulatus. J Hered 106:123-130

Mukherjee N, Mondol S, Andheria A, Ramakrishnan U (2007) Rapid multiplex based species identification of wild tigers using non-invasive samples. Conserv Genet 8:1465-1470

Fogden R, Dawnay N, McEwing R (2009) Wildlife DNA forensics-bridging the gap between conservation genetics and law enforcement. Endang Species Res 9: 179-195

* Pank M, Stanhope M, Natanson L, Kohler N, Shivji M (2001) Rapid and simultaneous identification of body parts from the morphologically similar sharks Carcharhinus obscures and Carcharhinus plumbeus (Carcharhinidae) using multiplex PCR. Mar Biotechnol (NY) 3:231-240

* Pinhal D, Shivji MS, Nachtigall PG, Chapman DD, Martins C (2012) A streamlined DNA tool for global identification of heavily exploited coastal shark species (genus Rhizoprionodon). PLOS ONE 7:e34797

Sambrook J, Russel DW (2006) Purification of nucleic acids by extraction with phenol:chloroform. CHS Protocols 1. http://cshprotocols.cshlp.org/content/2006/1/pdb. prot4455.long

Santana FM, Lessa RPT (2002) Análise demográfica do cação-quati, Isogomphod onoxyrhynchus na região norte do Brasil. III. Reunião da Sociedade Brasileira para o Estudo de Elasmobrânquios 3:90-91

Shivji MS (2010) DNA forensic applications in shark management and conservation. In: Carrier JC, Heithaus MR, Musick JA (eds) Sharks and their relatives. II: Biodiversity, adaptive physiology, and conservation. CRC Press, Boca Raton, FL, p 593-610

Shivji M, Clarke S, Pank M, Natanson L, Kohler N, Stanhope S (2002) Genetic identification of pelagic shark body parts for conservation and trade monitoring. Conserv Biol 16:1036-1047

*Ward RD, Zemlak TS, Innes BH, Last PR, Hebert PDN (2005) Barcoding Australia's fish species. Philos Trans R Soc B 360:1847-1857

Worm B, Davis B, Kettermer L, Ward-Paige CA and others (2013) Global catches, exploitation rates, and rebuilding options for sharks. Mar Policy 40:194-204

*Yao H, Song J, Liu C, Luo K and others (2010) Use of ITS2 region as the universal DNA barcode for plants and animals. PLOS ONE 5:e13102

Submitted: April 4, 2016; Accepted: November 26, 2016 Proofs received from author(s): February 6, 2017 